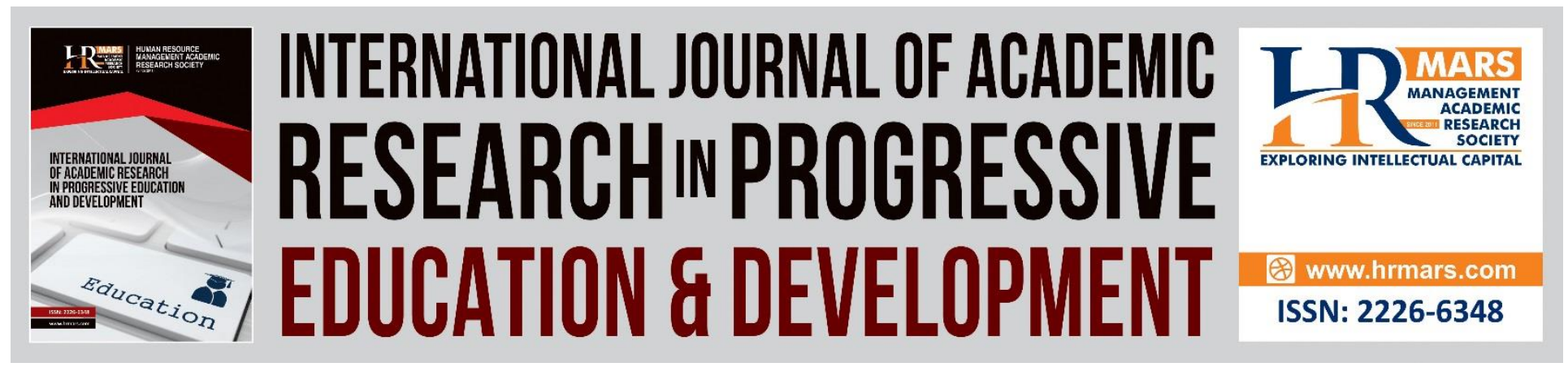

\title{
Factors Influencing Grade 10 Students' Career Choice in Mauritius
}

Bodhe-Surally Kaneez, Kisto Medha

To Link this Article: http://dx.doi.org/10.6007/IJARPED/v7-i2/4081 DOI: $10.6007 /$ IJARPED/v7-i2/4081

Received: 04 April 2018, Revised: 14 May 2018, Accepted: 15 May 2018

Published Online: 16 May 2018

In-Text Citation: (Kaneez \& Medha, 2018)

To Cite this Article: Kaneez, B.-S., \& Medha, K. (2018). Factors Influencing Grade 10 Students' Career Choice in Mauritius. International Journal of Academic Research in Progressive Education and Development, 7(2), 3044.

Copyright: (C) 2018 The Author(s)

Published by Human Resource Management Academic Research Society (www.hrmars.com)

This article is published under the Creative Commons Attribution (CC BY 4.0) license. Anyone may reproduce, distribute, translate and create derivative works of this article (for both commercial and non-commercial purposes), subject to full attribution to the original publication and authors. The full terms of this license may be seen at: http://creativecommons.org/licences/by/4.0/legalcode

Vol. 7, No. 2, April 2018, Pg. 30 - 44

http://hrmars.com/index.php/pages/detail/IJARPED

JOURNAL HOMEPAGE

Full Terms \& Conditions of access and use can be found at http://hrmars.com/index.php/pages/detail/publication-ethics 


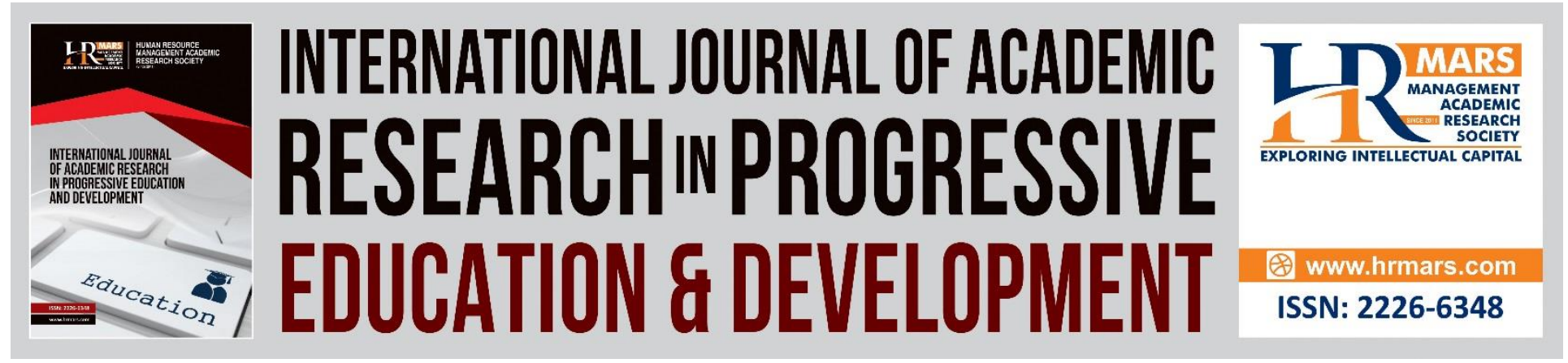

\title{
Factors influencing Grade 10 students' career choice in Mauritius
}

\author{
Bodhe-Surally Kaneez \\ PGCE in Business Education, BSc (Hons) Economics, Mauritius \\ Email: kaneez.bodhe-surally@outlook.com \\ Kisto Medha \\ MA Economics, BSc (Hons) Economics \& Finance, Mauritius \\ Email: medhakisto@gmail.com
}

\begin{abstract}
The purpose of this study was to determine factors influencing career choice among students of the fourth year of secondary education (also known as Grade 10) in Mauritius. Based on primary data which were sourced through survey among 400 students across the Island in 2016, both qualitative and quantitative analysis were done. There was evidence of parents influences on children's career choice. Most of students considered their academic performance and spent 1 to 3 months to decide what to study. Our results highlighted that students are happy with their present subject combination which is providing them with the necessary skills and training that they will need in the future to achieve their career goals. The findings also showed that many schools do not provide career guidance services. The key findings of the factor analysis showed that factors affecting students career choice can be grouped under three categories. The first group encompasses environment factors, followed by personality factors and lastly opportunity factors. Thus, from the findings, some recommendations were made to enable students to make informed decisions.
\end{abstract}

Keywords: Career Choice, Secondary Schools, Students, Mauritius

\section{Introduction}

For every student choosing the best course can be a difficult decision as well as thinking about their future career. Some students know exactly which course to pursue while others do not know. Career can be defined by the total pattern of one's activities held during a person's lifetime. It can also determine the individual personally because it describes who the person is. Therefore, choosing an appropriate career is very important for every individual (NCDA 2003) as this help to determine their future. However, with the advent of information technology, the emergence of post industrial revolution and job competition career choice turn out to be a 


\section{INTERNATIONAL JOURNAL OF ACADEMIC RESEARCH IN PROGRESSIVE EDUCATION AND}

DEVELOPMENT

Vol. 7, No. 2, April 2018, E-ISSN: 2226-6348 @ 2018 HRMARS

complex science. Thus, to cope with the evolving socio-economic conditions, there is a must for students to make an exhaustive career research and career planning to determine their career selection (Wattles, 2009). Throughout the journey, it is believed that students determine their career choices based on several factors. According to Kerka (2000), student career choice is influenced by the availability of information, cultural identity, finance, globalisation, interests, personality, role model, self- concept, social support and socialisation while for Bandura et al., (2001) an individual's career choice is influenced by their educational attainment, the context in which they live in, their personal aptitudes and social contacts. Moreover, Perrone et al., (2001) find that role model supportiveness and quality of relationship contribute to career choice of students, while Hewitt (2010) posits that individual career choice is influenced by their educational choices, income, some follow their parent careers, other opt to follow their passion regardless of the income obtained while others consider the extrinsic factors or intrinsic factors.

With the rapid growth in the socio economic of Mauritius, there is an increase need of people having the right skills and qualifications to join the services and the knowledge economy. Therefore, choosing a realistic career can be very daunting task especially in this competitive job market. Thus, it is apparent that students in Mauritius also face the problem of choosing an appropriate or relevant choice of subjects in schools. This leads to an issue of concern and has serious implications for the economy. Hence, guidance to Mauritian students are fundamental especially in choosing an appropriate or relevant choice of subjects in schools. Even though this topic is getting wider attention, yet no study has been conducted on career choice for Mauritius. Therefore, the main objective of this study is to elucidate the key factors that influence career choice among Grade 10 student in Mauritius. To identify the reasons influencing students' career choice, a questionnaire will be designed to gather primary data among 400 students across Mauritius. Both qualitative and quantitative analysis will be done. The rest of the paper is structured as follows: section 2 provides a literature review of the studies concerning students' career choice. Chapter 3 elaborates on the situational analysis of Mauritius, while chapter 4 sets out the methodology, reports and discusses the empirical results while section 5 concludes the paper.

\section{Literature Review}

A short definition of career can be the development and actions taken by a person throughout his/her lifetime, expressly related to that person's occupations. A career not only refer to one's position but also englobes the jobs held, titles earned, and work accomplished over a lengthy period. Thus, career selection is an extremely important decision that impacts an individual's entire future. Therefore, effective career exploration is a must, as the individual actively seeks out information from various professionals such as counsellors. This process can be stressful for the young adult, but variables that influence career exploration in adolescents should be identified and acknowledged. The factors underlying career choice led to mounting interest to educators, counsellors, ministers and social scientists. Some people maintain that the young adult does not exercise career choice, but their socio- economic environment determines their career choices, while others argue that the individual who exert a choice can either leads to a wise and fulfilling career choice or an unsatisfying choice. To better understand career choice, it is useful to study the viewpoints of economists, sociologists, psychologists and among others. 
While economists argued that the opportunities of the labour market strongly influence the vocational choices of people, sociologists pointed out that the forces in our society are the major determinants of vocational choice. The most significant factor in career choice is the birth right of the individual which tells about the individual family, nationality, race, residential district, social class and to large extent the educational and cultural opportunities for the person. The range of occupations chosen by an individual is largely determined by the status expectations of his social class (Friesen, 1981). Moreover, psychologist found that the inner world of the individual and the personality theory which comprise of psychoanalytic, trait, self and developmental theory play an important role in vocational choice. In addition, structural theorists are personality theorists who view human personality as a structured whole with distinctive attributes. These attributes are characteristic of the individual and are organised in a unique manner. It consists of psychoanalytic theory (the expression of the personality of the individual), self-concept theory (an attempt made by the person to express his sense of who he is in the job and in life generally (Friesen, 1981). The individual attempts to live out in his job by his aspirations, dreams, hopes and values. The degree of job satisfaction of the individual obtained from his job relates how happy he is) and need theory (relate to personal needs both at the conscious and unconscious level. The need hierarchy theory of Maslow is of growing concern for vocational counsellors). According to Friesen (1981), developmental theorists believe that career choice is expressed by total personality and it occurs over a progressive order which can be viewed as a longitudinally event. Four life stages namely growth, exploration, establishment and decline were proposed. The exploration phase occurs during high school and college where the young adult explores numerous career alternatives and must decide on his future career path. In short, the individual's environment, opportunity and personality will determine how the latter career choices.

The first factor affecting career choice may be the individual's environment which consists of the forces of family members, political issues, social and economic issue that student may deal with on daily basis. Parent's educational background may influence student views on whether to continue their education. These factors are used to nurture decisions in career choice. Kroll et al (1970) indicates that the decision-making process concerning one's career is mostly based on the process of maturity and planning. Opportunity is regarded as the second factor that affect students career choices. It may influence the students' preciseness about their future in terms of a realistic probability of a future career fields. It should be noted that not only careers and education affect the abilities to opportunities, but timing and location are very important in fulfilling ambitions. Opportunities in career choice include academic settings, entry-level job openings, industry contacts, job placement, job shadowing, technical schools and vocational guidance. Students show all the ambition, talent and skill needed for a career but if the student has not capitalised on the right locale at the right point in time, their hopes for that productive career are reduced. Personality is third determining factor that influences a chosen career. Students usually choose careers demand that matches his or her personality with the qualities of the job. Splaver (1977) posits that it is important for students to have a good understanding of themselves and their personality to make intelligent career plans. Personality factors consist of mental abilities (memory, numerical ability, reasoning ability, spatial ability, verbal 
Vol. 7, No. 2, April 2018, E-ISSN: 2226-6348 @ 2018 HRMARS

comprehension and word fluency ability), special abilities and interests. According to Kroll et al (1970), personality determinants include the entire cluster of biological and psychological attributes, as well as behavioural and physical features with genetic origins. The genetic determinants include endocrine systems, neurological, physical structures, sex and to some extent the intellectual and non-intellectual abilities and aptitudes. Rate of maturity is also a determinant.

There is sufficient empirical evidence to show that there are several factors contributing to the choice of student's career. Using the variance analysis with a sample of 405 secondary students in Kenya, Perrone et al., (2001) reports that the role model supportiveness and quality of relationship contributed to the career choice of students. The role model might be someone from their peer group, parent or teachers. Students own interests and motivation from parents affect student career choices. It was also noted that anticipated earnings are the most influential factors for males while females were mostly influenced by prestigious positions. Role-model relationship quality and role-model supportiveness also influence the individual career decision. Moreover, a study on career choice by Kniveton (2004) with a sample of 348 Singaporean youngsters between the age range of 14-18 years finds that parents have a greater influence than teachers on student's career choice. He finds the gender effect where students having the same sex with the parent influence their career choice greatly. He further notes that birth order plays a significant role in career choice. The eldest child is more influenced by the father while the youngest is influenced by the mother. Choice of career was least likely to be dependent on self-development or career development, but rather it was motivated by financial reward and interest for the job. Similarly, the study of Bojuwoye et al (2006) attempt to investigate factors that influence career decisions with a sample of 80 technical students with mean age of 22 years in Africa. The study reveals that academic performance, appropriate communications within the family, parental high expectations of children, peer pressure, prestige statuses of some occupations, school curricular subjects and teacher influences affect career choices positively. They further note that finance, lack of appropriate information, poor academic performance and unsatisfactory career counselling services are among the barriers to career choices.

Using 12 focus groups from 11-county rural area in Central Pennsylvania, Ferry (2006) report that the interdependence of family, school, and community culture played a critical role in shaping the youth's occupational choice. Economic and social factors influence the youth's perceptions of appropriate career choices. Further the study reveals that college-bound and work-bound young adults are influenced differently by social and economic contextual factors in their job hunt. She notes that the lack of family involvement in the career choice process influence the youth inabilities to make decisions. All the young adults confirm that lack of financial resources to attend additional schooling or training was their major barriers. The second most identifies barriers for college-bound youth is college acceptance and being capable of graduating, while the lack of employment opportunities to achieve their employment goals for work-bound youth. The study further confirms that majority of the youth intends to leave the rural area to seek employment. Moreover, based on a study done by Onoyase and Onoyase (2009) in Nigeria among 616 secondary school students in Federal Government colleges, the authors attempt to find out the relationship between personality types and career choice of secondary school 


\section{INTERNATIONAL JOURNAL OF ACADEMIC RESEARCH IN PROGRESSIVE EDUCATION AND}

\section{DEVELOPMENT}

Vol. 7, No. 2, April 2018, E-ISSN: 2226-6348 @ 2018 HRMARS

students. The authors use the Holland's grouping of personality types into six categories namely realistic, investigative, social, artistic, enterprising and conventional. The study reveals that there was no relationship was found between realistic, investigative personality type and career choice. Further the results show a significant relationship between the social, artistic, enterprising and conventional personality type and career choice. Based on a survey of 332 secondary students in Kisumu Municipality Kenya, Edwards and Quinter (2011) attempt to determine the influential factors in students' career choices. They find that the most influential factor for students' career choices are outcome expectancies, individual variants such as gender, personal interests, learning experiences, environmental factors and personal contacts. Gender and the environment are among the least influential ones. Family members affect the students' career choices. The study further reveals that the career choice determinant among male are learning experiences and career flexibility, while females choose availability of advancement opportunity and opportunity to apply skills. Advice from peer was less important as compared to family members, teachers and career counsellors. Teachers are more influential compared to career counsellors.

The Korir and Wafula (2012) study attempt to examine the influential factors in student career choice among students undertaking hospitality management in Moi University. Using the stratified and systematic random sampling techniques with a sample of 120 students, the findings show that majority of students are influenced by opportunity (technical schools and job opening) followed by environmental factors (external influencers and advertisements made by institution) while least influenced by personal factors (personal interest and lifestyle of those who are already in the hospitality industry). They also point out that students opted, selected and preferred hospitality careers despite many other alternatives that were open to them. The study also reveals that academic setting, access to the institution, course entry level, family tradition, income, industry conducts, job placements, job shadowing do not influence their choice of hospitality career. A study carried out by Shumba and Naong (2012) among 133 South African university students to explore factors influencing career choice and aspirations, confirms that family, the ability of the learner self to identify his/her preferred career choice, and teachers are among the most influencing factors in career choice and aspirations of students. The study also find that career choices are decided long before the leaners come to universities. Very few students change their study program since these learners knew what they intended to study after completing their Grade 12. They also point out that once the students have got their first choice of what they wanted to pursue in their studies, they also make their career choices. Moreover, using a sample of 100 respondents from five secondary schools in Ogun State, Olamide and Olawaiye (2013) confirm that environment, influence and opportunity factors influence student's career choice. The study points out that the influence of people in the closer circle of friends, family, and academia does not influence or lead students in deciding their career choice. They also note that students whose parents have advanced education do influence their career choice. The response shows that students concerned with financial responsibility might already be working to make some saving for an educational future.

The study of Obiunu and Ebunu (2013) attempt to examine factors affecting career choice in Ethiope East Local Government Area of Delta State. Based on a sample size of 60 secondary school students, the authors find that situational factors, environment factors and educational 
DEVELOPMENT

Vol. 7, No. 2, April 2018, E-ISSN: 2226-6348 @ 2018 HRMARS

factors affect students career choice positively. Personality factors and economics factors had no effect on career choice. Moreover, in a recent study of Ooro et at (2017) attempts to determine the factors influencing the career choice among 231 students in Business and Economics in Kisii University. Using a stratified random sampling, the study reveals that gender is the most influencing factor to career choice, followed by age. Students point out that factors of career experience affect their career choice. The student develops an interest in a previous career before training. The study also reveals that expected financial reward motivates the students in choosing a specific career based on the salary they are expecting on the time of employment. Thus, the empirical analysis on the topic of career choice is getting wider attention now, but, unfortunately there is little research concerning career choice of student in Mauritius, thus the current paper will attempt to fill the gaps in literature by identifying factors affecting career choice of Grade 10 students in Mauritius.

\section{Situational Analysis of Mauritius}

The history of education in Mauritius can be traced back to 1767 with the opening of the first school in Port Louis where only a few privileged children had access to education. Mass education was prevalent in the 1815 and it progressed slowly, but in 1950 educational development led to the expansion of both government and aided primary schools based on a government sponsored program of 'education for all'. Since the independence in 1968, there has been a continuous attempt to improve and modernise the education system. In 2003, the 'ranking system' was responsible for the intense competition at the primary level, which led to severe problem, hence, it was replaced by the 'grade system'. Much emphasis was put the academic aspect of education at the cost of the technical and vocational skills necessary for direct employment. Since education is considered as the pillar to economic and social progress, government provided free schooling (funded by taxes) from primary level till postsecondary level. It has also met the millennium goal by achieving the universal primary education. An increase in literacy rate between 15 to 24 years was also witnessed. The Mauritian educational system consists of the pre-primary, primary, secondary schools, technical/vocational and tertiary. The main national examination of primary school is the Certificate of Primary Education which takes in standard VI and is highly competitive. This examination serves the dual purposes of certification and eligibility for admission to secondary school. The main examination in secondary school are Cambridge school certificate or the General certificate of education (Ordinary Level) which cover both core subjects and a wide range of options and the Higher school certificate or the general certificate of education (A- level) where students must specialise in 3 main subjects and 2 subsidiary ones. Both exams are carried out by the university of Cambridge through the university of Cambridge international examinations, which devises the syllabus; prepares and prints the examinations papers and correct some subjects. Moreover, it should be noted that Form 3 is the grade where students choose subjects which they will study and examine at Form 4 and 5 level. The choice of subjects depends on options provided by the school except for English, French and Mathematics, which are compulsory. This helps to determine the student's ability to learn a subject, which might in turn determine their career. Thus, we further note that the number of students enrolled in Grade 10 was 18,160 for all school in 2016. From 2000 till 2016, the total enrollment of students increases very slightly by 1853 . The enrollment for both female and male follow the same trend. We further look at the total enrolment in Grade 10 for the year 2016 by age. The statistics shows 


\section{INTERNATIONAL JOURNAL OF ACADEMIC RESEARCH IN PROGRESSIVE EDUCATION AND}

\section{DEVELOPMENT}

Vol. 7, No. 2, April 2018, E-ISSN: 2226-6348 @ 2018 HRMARS

less enrolment in grade 10 at the age of 13, while the maximum number enrolled is within the age range of 14 and 15 years and the less student tends to enroll within the age range of 18 to 19 years. Further it was noted that in 2016, there was 2957 number of repeaters in Grade 10 around the Island of Mauritius.

\section{Methodology, Data Analysis and Key Findings}

Using the descriptive survey research design, we design a questionnaire to collect data among student of the fourth year of secondary education in Mauritius. The questionnaire was divided into three sections. The first section focuses on the general profile of the student. In the second section, respondents were asked about their subject choice while the third section contains questions about assessment of their subject choice. A sample of 400 students in Grade 10 were randomly chosen to fill the questionnaires. The descriptive analysis will be done using Microsoft office 2010 while the cross tabulation, multiple responses analysis, correlation, ranking \& scoring, factor analysis and one sample t- test will be done using the Statistical Package for the Social Sciences (SPSS) software version 21. The Pearson correlation test is carried out to find the relationship between two variables, where the null hypothesis says that there is no relationship between two variables, while, the alternative hypothesis says there is a relationship between these two variables. To determine factors influencing students' subject choice based on parent point of view, the ranking and scoring will be used, where ranking basically means positioning numerous options in order of importance, value or preference while scoring means assigning values to different options, based on some convenient scale. Additionally, the factor analysis which is a statistical and data-reduction technique, will be used to analyse factors influencing the student career choice based on Likert scale.

According to the survey results $50.50 \%$ of the students are female while $49.50 \%$ are male. Predominantly, the participants are 14 years old. Most of respondents (45.75\%) have only 1 sibling. Looking at the distribution of parent educational attainment, the highest percentage of parents have attained secondary education while vocational training is least of all. Exploring the respondents' father work, we note that $74.75 \%$ of them work out of which $27.75 \%$ are in private sector, $21.25 \%$ in public sector, $10.75 \%$ in their own business and $5 \%$ in family business. Looking at father occupation, $24.50 \%$ belong to technicians and associate professionals, $12.50 \%$ do elementary work while $11.75 \%$ are engaged in services jobs. An in-depth analysis was done on the monthly income of students' father and there was evidence that $50.75 \%$ earned between Rs. 15,000 - Rs. $37,500,13.25 \%$ earn above Rs. 37,500 whilst $10.75 \%$ earn less than Rs. 15,000 . It was noted that $25.25 \%$ of respondents' father who does not work, out of which $12.00 \%$ of them have deceased while $0.75 \%$ has health problems. $62 \%$ of respondents confirm that their mother work, out of which $24 \%$ are in private sector, $23.50 \%$ in public sector, $5 \%$ in family business and $3 \%$ in their own business. $22.50 \%$ of respondents' mother work as technicians and associate professionals, $11 \%$ as clerks, $8.75 \%$ do elementary work while $8 \%$ are services workers. With further analysis done on monthly income of student's mother, it has been observed that the majority earn between Rs. 15,000 - Rs. 37,500, whilst $12.25 \%$ earn less than Rs. 15,000 and only $3.50 \%$ earn above Rs. 37,500 . It was also noted that out of $38 \%$ of respondents' mother who do not work: $15.50 \%$ have household responsibilities/childbirth, $11.50 \%$ are not interested to work while $5.25 \%$ have deceased and $3 \%$ are constraint by health problems. 
According to our statistics, $41.50 \%$ of parents prove to be the major influencing factor in determining their children's career choice, followed by $35.25 \%$ of the ability of the learner self, $7 \%$ of family and $7 \%$ friends. We further note that female students are mostly influenced by counsellors and family members in their career decision, whilst teacher and no one among male students. An in-depth analysis was done on factors influencing student career choice across age and gender. It was noted that $6.25 \%$ of 13 years female students' identity their own career choice while the $13.75 \%$ of 14 years and $151.25 \%$ of female students are influenced by their parents. The survey data points out that in all age categories, male students are mostly influenced by their parents. $37.75 \%$ of students consider their academic performance to make their career decision. Very few students rely on salary of the work to decide what to study. We further note that female students aged 13 years mostly consider the decision made with their parents while 14 years old consider their academic performance and 15 years consider the job market understanding. Moreover, most of male students across all age bracket consider their academic performance to choose what to study. We also attempt to enquire about the time spent by student to research about their career choice, $57.25 \%$ of students spent 1 to 3 months, $28 \%$ spent less than 1 month while $10.50 \%$ of students spent 3-6 months to decide for their career choice. $94.50 \%$ of students were given the subjects which they applied for, while $5.50 \%$ were given different subjects. $4.50 \%$ were female and $2 \%$ were male students regret registering their current course. It was corroborated that $9 \%$ of female and $7.50 \%$ of male students changed their course. $8.50 \%$ of students changed their program as the initial course was too demanding while $3.25 \%$ failed their previous program and $2.50 \%$ did not like the initial course.

The survey further reveals that $93.50 \%$ of students who did not regret doing the course, $80.75 \%$ among them did not change their present program while $12.75 \%$ had changed the program. Out of $6.50 \%$ of student who regret doing the course, only $3.75 \%$ of them had changed their program. $43.75 \%$ female and $39.50 \%$ male students plan to go university. $93.50 \%$ of students who do not regret doing their current course: $15.50 \%$ (5.75\% of female and $9.75 \%$ of male) have no plan to go to university while $78 \%$ ( $40.25 \%$ of female and $37.75 \%$ of male) intend to go to university. Furthermore, out of $6.50 \%$ of students who regret doing their current course only $1.25 \%(1.00 \%$ of female and $0.25 \%$ of male) have no plan to go university while the rest $5.25 \%$ (3.50\% of female and $1.75 \%$ of male) intend to go university. Out of $83.50 \%$ of students who did not change their current course: $12.25 \%$ (4.75\% of female and $7.50 \%$ of male) have no plan to go to university while $71.25 \%$ (36.75\% of female and $34.50 \%$ of male) intend to go university. Out of $16.50 \%$ of students who changed their current course, $4.50 \%$ (2.00\% of female and $2.05 \%$ of male) have no plan to go university while the rest $12.00 \%$ (7.00\% of female and $5.00 \%$ of male) will go to university. It was also noted that only $30.25 \%$ of female and $25.75 \%$ of male respondents have employment goals. Further, respondents were asked about three factors that influence their career choice. The survey reveals that the three most influencing factors of career choice are: $27.50 \%$ said educational attainment, $22.58 \%$ find environment (cultural \& social context of family \& community) and $12.83 \%$ find cognitive abilities. $64 \%$ of respondents were not aware of any guidance provided for career choice while only $36 \%$ respond positively to the question. Among those students who agreed upon having knowledge on career guidance, $39.42 \%$ (23.56\% being female respondents and $15.87 \%$ being male $15.87 \%$ ) had access to information by attending 
DEVELOPMENT

Vol. 7, No. 2, April 2018, E-ISSN: 2226-6348 @ 2018 HRMARS

guest speakers to guide \& counsel students in schools, while $30.77 \%$ respondents $(20.19 \%$ being female and $10.58 \%$ being male) gain information via seminars from teacher counsellors. Least of all, $12.02 \%$ (9.18\% female and $2.88 \%$ male) were provided information by schools through literature materials. Students at the age of 14 recorded the higher percentage $(22 \%)$ of being aware of career guidance.

Based on the data collected, the correlation test between awareness of guidance \& counselling and school provided guidance \& counselling demonstrates that our null hypothesis is positively significant; consequently, the alternative hypothesis is accepted. Thus, we can conclude that that higher awareness of guidance \& counselling services among student, the more school provide guidance \& counselling services. Furthermore, it was observed that $63.75 \%$ of schools do not provide career guidance services compared to $36.25 \%$ of respondents claimed that school provided them with guidance services. Further to this, respondents were asked which types of guidance they received from school. Respondent's opinion relates to three suggestions: $50.79 \%$ through provision of career guidance, $41.27 \%$ through educational guidance and $7.94 \%$ psychological and social factors. Respondents were also asked to give their opinion regarding guidance \& counselling services obtained by school, $36 \%$ of respondents consider it to be important in secondary school. The correlation test between guidance \& counselling services at school and guidance \& counselling services being important is strongly positive correlated, implying that the more school provide guidance \& counselling services, the more students finds the counselling services important. $27.50 \%$ of students are agreeable with the fact that guidance \& counselling service are interesting and the positive correlation between guidance \& counselling services at school and guidance \& counselling services being interesting imply that the more school provide guidance \& counselling services, the more students finds the counselling services interesting. Furthermore, $30.75 \%$ of respondents find the guidance \& counselling services to be useful. The positive correlation between guidance \& counselling services at school and guidance $\&$ counselling services being useful indicate that the more school provide guidance $\&$ counselling services, the more students finds the services useful.

Based on the student's point of view, the three main challenges of guidance \& counselling in schools are: $27.17 \%$ of students are unwilling to discuss their problems, $22.92 \%$ lack of reading and reference material resources and $21.92 \%$ did not receive support from department. The least influencing challenges are education is too bulky and influence of peer. Moreover, 39.63\% students prefer their friends to be their source of counselling, followed by their teacher and parents. We further note that the source of counselling varies across gender, while the preferred source among female students are friends, peer counsellor and teacher, male students consider their friends, teacher and parents. However, families, school principal and counsellor agents are the least considered source of counselling among the respondents. Further to this, respondents were given five options and had to rank in order of preference based on their parent influence on their subject choice. The calculation of scores for the whole sample finds that Option 5 is ranked 1st, Option 2 is ranked $2^{\text {nd }}$, Option 3 is ranked $3^{\text {rd }}$, Option 4 is ranked $4^{\text {th }}$ while Option 1 is ranked last. It should be noted that the ranking and scoring results vary among gender, as reported in Table 1. 
INTERNATIONAL JOURNAL OF ACADEMIC RESEARCH IN PROGRESSIVE EDUCATION AND

DEVELOPMENT

Vol. 7, No. 2, April 2018, E-ISSN: 2226-6348 @ 2018 HRMARS

Table 1: Results of Ranking \& Scoring

\begin{tabular}{|l|c|c|c|}
\hline Variables & Total & $\begin{array}{l}\text { Fema } \\
\text { le }\end{array}$ & Male \\
\hline Option 1- My parents expect me to enter university. & $5^{\text {th }}$ & $5^{\text {th }}$ & $4^{\text {th }}$ \\
\hline $\begin{array}{l}\text { Option 2- My parents expect me to pick up a skill/ trade after } \\
\text { secondary school to start working }\end{array}$ & $2^{\text {nd }}$ & $4^{\text {th }}$ & $2^{\text {nd }}$ \\
\hline $\begin{array}{l}\text { Option 3- My parents expect me to pursue a career that they feel is } \\
\text { appropriate }\end{array}$ & $3^{\text {rd }}$ & $3^{\text {rd }}$ & $3^{\text {rd }}$ \\
\hline $\begin{array}{l}\text { Option 4- My parents have frequent discussions with me concerning } \\
\text { future jobs opportunities. }\end{array}$ & $4^{\text {th }}$ & $2^{\text {nd }}$ & $5^{\text {th }}$ \\
\hline $\begin{array}{l}\text { Option 5- My parents probably know better than anyone which } \\
\text { occupation I should enter }\end{array}$ & $1^{\text {st }}$ & $1^{\text {st }}$ & $1^{\text {st }}$ \\
\hline
\end{tabular}

Source: Survey Data, 2017

Further, students were asked questions for four variables regarding the present subject combination. It was noted that the mean of all the variables was more than 2.5 (the average level of satisfaction). The analysis demonstrates that the mean level for all the four variables lies between 3 and 4 according to degree of satisfaction with five-scale ranking, we assumed that our null hypothesis is the mean response of 3 for all four variables. With a significance level of 0.000 for all four variables, the alternative hypotheses are accepted with high level of confidence. Thus, from a practical standpoint, the conclusion drawn is: students were happy with their present subject combination, they feel that their present subject combination is limiting their career opportunities, they feel that their present subject combination provide them with the necessary skills and training that they need for the future and they also feel that their present subject combination will help them to achieve their career goals.

Next, we proceed with the factor analysis. Firstly, the Cronbach alpha is 0.866 for 15 items, which is a reasonable test of scale reliability. Looking at the KMO value, the Bartlett's test is significant $(p=.000)$ with KMO value of 0.855 . We next proceed to find the communalities, and we note that all the variables are well and completely fitted with the factor solution, no variable was dropped from the analysis. The total variance explained is $62.04 \%$, and four components explain or capture the remaining components. The results of parallel analysis retain only three factors for further investigation. Thus, components 1, 2 and 3 explain or capture much more of the variance than the remaining components. To help in the interpretation, the varimax rotation is performed. The three components explain a total of $55.24 \%$ of the variance, meaning $55.24 \%$ of the total variation in factors influencing the student career choice is explained by cumulative effect of the 3 components extracted. We further find the rotated component matrix which shows the loading of the factors can be grouped into 3 principle components. The first group contains variables social media, school attended, self- employment opportunity, self-motivation, gender, lifestyle. The second component encompasses factors personal skills, labour market, personal interests, learning experience, industry trends, prestige associated with the profession, while the last group can be grouped factors such as area of residence, academic performance and financial rewards. These results will be highly useful for policy recommendations. 


\section{Summary, Conclusion \& Policy Implications}

This study has dealt with the career choice issue among Grade 10 students in Mauritius. We attempt to explore the main variables that influence the student career choice. A questionnaire was designed to collect primary data among 400 students across Mauritius. The findings show that majority of students are influenced by environment and personality factors and not influenced by opportunity factors. The results are remarkably supportive that parental influence have significant effect on the career choice of their children. This supports the work of Friesen (1981), which stated the social and economic environment determines the vocational choices of an individual and parents are influential in the career development process. The three most influencing factors of career choice are: educational attainment, cultural \& social context of family \& community and cognitive abilities. Further, it was observed that about $89 \%$ of respondents spent less time in the career choice process. The less time spent might result in a failure. It was further observed that most of the students did not regret doing their present course. The findings also show that more than half of respondents were not aware of any career guidance and the majority of respondent points out that they did not benefit from any career guidance from their school.

The study recommends career education to enable students make informed decisions. Students need career guidance to assist them in their choice. In addition, career guidance should be provided on a regular basis. Career counselors should be conscious of environment and personal factors affect career decision while guiding the students aiming to provide appropriate information with regards to their career and future stability. Students should be encouraged to go to job fairs once they enter secondary school to know about the current and future trends in the job market. Schools should also encourage presentations by experts on qualifications and job prospects among first year of secondary school student. Schools and businesses could partner to provide life scenario and problem- solving situations which will in turn be benefit to the student in terms of practice and experiment. Career choice is an ever-evolving process which includes experimentation, trial and error, decision- making and eventual judgment, thus, students must be made aware of this process at an early age aiming to do the right decision.

\section{References}

1. Bandura, A. Barbaranelli, C. Caprara, G.V. \& Pastorelli, C. (2001). Self-efficacy beliefs as shapers of children's aspirations and career trajectories. Child Development, 72, pp. 187-206.

2. Bojuwoye, O. \& Mbanjwa, S. (2006). Factors impacting on career choices of Technikon students from previously disadvantaged high schools. Journal of Psychology in Africa, 1, pp. 3-16.

3. Chen, C.P. (1997). Career projection: Narrative in context. Journal of Vocational Behavior, 54, pp. 279-295.

4. Dick, T. P. \& Rallis, S.F. (1991). Factors and influences of high school students' career choices. Journal of Research in Mathematics Education, vol. 4, no. 22, pp. 281-292. 
INTERNATIONAL JOURNAL OF ACADEMIC RESEARCH IN PROGRESSIVE EDUCATION AND DEVELOPMENT

Vol. 7, No. 2, April 2018, E-ISSN: 2226-6348 @ 2018 HRMARS

5. Edwards, K. \& Quinter, M. (2011). Factors influencing students career choices among secondary school students in Kisumu Municipality, Kenya. Journal of Emerging Trends in Educational Research and Policy Studies, vol. 2, no. 2, pp. 81-87

6. Ferry, N. M. (2006). Factors influencing career choices of adolescents and young adults in rural Pennsylvania. Journal of Extension, vol. 44, no. 3.

7. Friesen, J. D. (1981). Vocational Counselling: Help from the Social Sciences. Direction (Winnipeg, MB).

8. Hewitt, J. (2010). Factors influencing career choice. Available from www.ehow.com. Accessed on 15/12/2017.

9. Obinnu, J. J. \& Ebunu, O. R. (2013). Situational factors as correlates of secondary school adolescents students career choice in Ethiope East Local Government Area of Delta State. International Review of Social Sciences and Humanities, vol. 5, issue. 2, pp. 106114.

10. Kerka, S. (2000). Career development, gender, race and class. Eric Clearing house on Adult Career and Vocational Education Columbus. ED 421641.

11. Kniveton, B. H. (2004). The influences and motivations on which students base their choice of career. Journal of Research in Education, 72, pp. 47-59.

12. Korir, J. \& Wafula, W. (2012). Factors that influence career choice of hospitality students in Moi University, Kenya. Journal of Education and Practice, vol. 3, no. 14, pp. 83-90.

13. Kroll, A. Dinklage, L. Lee, J. Morley, E. \& Wilson, E. (1970). Development in career. Albany, New York, NY: John Wiley \& Sons, Inc.

14. National Career Development Association NCDA. (2003). Career Development: A Policy Statement of the National Career Development Association Board of Directors, Adapted March 16th (1993), Revised (2003), http://ncda.org.

15. Olamide, S.O. \& Olawaiye, S.O. (2013). The factors determining the choice of career among secondary school students. The International Journal Of Engineering and Science, vol. 2 , no. 6, pp. 33-44.

16. Olaosebikan, O. I. \& Olusakin A. M. (2014). Effects of parental influence on adolescents' career choice in Badagry local government area of Lagos State, Nigeria. IOSR Journal of Research \& Method in Education (IOSR-JRME), vol. 4, issue. 4, pp. 44-57.

17. Onoyase, D. \& Onoyase, A. (2009). The relationship between personality types and career choice of secondary school students in Federal government colleges in Nigeria. Anthropologist, vol. 11, no. 2, pp. 109-115.

18. Ooro, H. O. H. Omari, S. \& Mong'are O. (2017). An assessment of factors influencing career choices among university students: A survey of students in the school of business and economics, Kisii University. IOSR Journal of Humanities and Social Science (IOSRJHSS), vol.22, issue. 11, pp. 82-91, 2017.

19. Perrone, K. M. Sedlacek, E. W. \& Alexander, M. C. (2001). Gender and ethnic differences in career goal attainment. Career Development Quarterly, vol. 50, no. 2, pp.168-178.

20. Perrone, K.M. Zanardelli, G. Worthington, E. L. \& Chartrand, J. M. (2002). Role model influence on the career decidedness of college students. Project innovation (Alabama) United States.

21. Shumba, A. \& Naong, M. (2012). Factors influencing students' career choice and aspirations in south Africa. Journal of Social Science, vol. 33, no. 2, pp. 169-178. 
INTERNATIONAL JOURNAL OF ACADEMIC RESEARCH IN PROGRESSIVE EDUCATION AND DEVELOPMENT

Vol. 7, No. 2, April 2018, E-ISSN: 2226-6348 @ 2018 HRMARS

22. Splaver, S. (1977). Your personality and your career. New York, NY: Julian Messner.

23. Statistics Mauritius website: http://statsmauritius.govmu.org

24. Wattles, D.W. (2009). The science of getting rich. Available on: www.thescienceofgettingrich.net. Accessed on 12/12/2017.

\section{Corresponding Author}

Kisto Medha

MA Economics (Collaborative Programme), with Specialisation in Labour Economics \& International Economics, Bachelor of Science (Hons) Economics and Finance

Independent Researcher

Royal Road, Verdun, Mauritius

Email: medhakisto@gmail.com 
INTERNATIONAL JOURNAL OF ACADEMIC RESEARCH IN PROGRESSIVE EDUCATION AND DEVELOPMENT

Vol. 7, No. 2, April 2018, E-ISSN: $2226-6348$ @ 2018 HRMARS 